\title{
(ㄷ)
}

Research Paper

EPRA International Journal of Economic and Business Review-Peer Reviewed Journal

Volume - 8, Issue -10, October 2020 |e-ISSN: 2347 - 9671| p- ISSN: 2349 - 0187

SJIF Impact Factor (2020): 8.107|| ISI Value: 1.433|| Journal DOI URL: https://doi.org/10.36713/epra2012

\section{PAROLE AND PROBATION AS REMEDY FOR NIGERIA'S PRISON CONGESTION PROBLEM}

\author{
${ }^{1}$ Gbenemene kpae (Ph.D)
}

${ }^{1}$ University of Port Harcourt, Nigeria

\section{ABSTRACT}

Article DOI URL: https://doi.org/10.36713/epra5446

The Nigeria criminal justice system, particularly the penitentiary has been plaque with a lot of problems especially the issue of overcrowding and the poor living condition of inmates. Majority of the inmates are those awaiting trial, or ATP. The poor condition of the prison makes many prisoners to develop mental problems. Over the years, various reforms have been introduced by Comptroller General of prisons, but these reforms have failed to address the issue of prison congestion. Instead of the prisons to serve their fundamental purpose, which is reformation and rehabilitation of criminal offenders they have become a breeding place for hardened criminals. Many incarcerated offenders become recidivist immediately they are released from prison custody. This paper examines the problem of prison congestion in Nigeria. The Marxian class analysis is used as a theoretical framework to understand Nigeria's prison congestion problem. Marxist theorists will contend that recidivism is prevalent among the people of lower class than the privileged and affluent class because they do not have the financial resources to secure early release on bail from prison or prosecute any criminal charges leveled against them. It recommends the adoption of community-based corrections such probation and parole as alternative to incarceration as solution to Nigeria's prison overcrowding.

KEYWORDS: Probation, parole, community corrections, prison congestion

\section{INTRODUCTION}

The prison condition in Nigeria is dehumanizing. Many inmates develop mental problems as a result of serving time in prison custody. The poor state of the prison is either due to inadequate funding and overcrowding. According to a senate committee on Interior who embarked on a tour of prisons in the country recently, they were shocked by the dilapidating condition of most prisons they visited and that they were no longer fit for human habitation. In their annual report the Senate committee noted that majority of the cells leak during the rains and the perimeter walls and some cells have, in some cases collapsed. The report signed by the Chairman of the committee, Senator Olalekan Mustapha stated that the committee was moved by the plight of the inmates because many cells meant to accommodate about 50 inmates accommodate about 150 inmates all cramped together (Olaolu, Olusina et al, 2014).

One of the fundamental causes of Nigeria's prison congestion is due to the type of judicial system that the country operates. Overwhelming majority of the inmates in custody in the nation's penitentiary are those awaiting trial. Many have spent time in prison far exceeding the time; they would have spent if convicted. The situation of Nigerian prison and the plight of 
prisoners were made quite clearer during the visit of Captain Emmanuel Iheanacho, a former Minister for Interior to Kuje prison Abuja last year. During the former Minister's visit, he discovered that some inmates had been awaiting trial for over 10 years, and many blamed their woes on the judicial system and the tough condition required for bail (Olaolu Olusina et al, 2014). The emphasis of the Nigerian criminal justice is punishment and deterrence, not rehabilitation of criminal offenders. The system does not take into cognizance those who are accused of misdemeanor offenses. Since the goal is to punish suspected criminal offenders, any person accused of having committed a crime is sent to prison. However, since the judiciary is already clogged with so many cases, many suspects are sent to prison pending when their cases will be charged to court. The conditions of most prisons and detention centers are so deplorable that they are unsuitable for human habitation. Our argument in this paper is that the Nigerian criminal justice system should adopt an alternative form of punishment such as probation, and parole rather than incarceration which have failed to reform the criminals but has turn many of them into becoming hardened criminals and recidivist.

\section{CONCEPTUAL CLARIFICATION Prison}

Prisons are long-time government-sanctioned facilities designed for the long-term confinement of adults as punishment for serious offences (Rubin \& Deflem, 2019). A prison is also a place for the confinement of persons who have been remanded or held in custody by a judicial authority or who have been deprived of their liberty following a conviction for a crime (Coyle,

\section{History of Prison}

Prisons are government-sanctioned facilities designed for The earliest records of prisons come from the ancient civilizations of Mesopotamia and Egypt. During those times, prisons were almost always stationed in the underground dungeons where guilty or suspected criminals spent their life either awaiting death sentence, or a command to become slaves (often working as galley slaves. Except in Greece where prisoners were held in poorly isolated buildings where they could be visited by family members and friends. The primary source of their detention was not dungeons, high walls or bars, but simple wooden blocks attached to their feet. Ancient Roman Empire however continued to use harsher methods. Their prisons were built almost exclusively underground, with tight and claustrophobic passageways and cells. Prisoners themselves were held either in simple cells or chained to the walls, for life or for time. As slavery was accepted norm then, majority of prisoners that were not sentenced to death were sold as slaves or used by the Roman government as workforce, while some were used as gladiators. In 1166 Henry II commissioned the construction of the first prison and the drafting of the English legal system and the introduction of the concept of a jury. In 1215, King John signed the Magna Carta which stated that no man could be imprisoned without trial.

Rubin (2018) believes that the concept of prison as is now known today played little role in western criminal jurisprudence until the $19^{\text {th }}$ century. The concept of incarceration or long prison sentence that served as punishment was none existent. Rather criminal offenders were subjected to public capital and corporal punishment. Many jurisdictions in Europe employed jails but were not primary places of punishment. They were sometimes referred to as "gaol" or county prison in colonial America or early modern Europe that contained vagrants, beggars, debtors, witnesses, those confined for execution and petty criminals until they paid their fines. Other forms of punishment emerged in the $17^{\text {th }}$ and $18^{\text {th }}$ centuries that became forerunner to the modern prison system, but they involved restriction of the freedom of the inmates including forced labour. Mediterranean countries set convicts to rowing in large ships, a punishment called 'galley slavery,' while in France convicts were sent to labour camps near decommissioned ships. In England, convicts were sent to the New World for twelve or fourteen years for hard labour through a system known as "convict transportation". When the American Revolution halted the practice in 1776, prisoners were sent to the hulks, or moored ships that held the overflow of prisoners from local jails or bridewells, but were eventually shipped to Australia when transportation resumed. The most important forerunner of the modern prison is the workhouse. Workhouses existed throughout the western world during the $16^{\text {th }}$ and $18^{\text {th }}$ centuries usually used as a place where people of low status were subjected to forced labour. In the Dutch Republic, workhouses were used to subject vagrant and beggars to hard labours with the intention of reforming them from their life of idleness.

The concept of the modern prison came from the works of Cesare Baccaria and John Howard that influenced the establishment of prisons in American states of Connecticut, Massachusetts and Pennsylvania between 1785 and 1794. But in the end, the Walnut Street Prison in Philadelphia became the most influential, where most American states would model their prison from. But the idea of solitary confinement of hardened criminals was introduced in New York's Auburn State Prison in 1816.

The emergence of the concept of penitentiary, that is, a place of confinement and reform came with the works of Jeremy Bentham, an English Jurist and Philosopher and John Howard, who after visit to several prisons in England and Wales wrote a book 
titled "the state of prisons in England and Wales" in 1777, and "An Account of Principal Lazarettos in Europe" in 1789 (Coyle, 2020).

\section{Purpose of Imprisonment}

Imprisonment was introduced for two main purposes, first is to deter those that would contemplate criminal behavior (general deterrence) and to make it less likely that those after serving prison term will commit crimes after release from prison (individual deterrence). Second, to obtain retribution from those who have committed crimes. Third, to reform those who are sent to prison. Finally, to protect the public from those who commit crimes, especially repeat offenders. However, the increasing use of reform rather than punishment has led to prison systems to be called 'correctional institutions' Coyle, 2020). This description of imprisonment only applies to Europe and North America. Most African countries had the idea of modern prison through European colonialism. In Nigeria, for instance, prisons were introduced after the British colonization in 1865 . Before the introduction of prison system in Nigeria, most native people used restitution, retribution and banishment to deal with criminal behavior, while some criminals were sold into slavery.

\section{Prison Trend in Nigeria}

Table 1: Prison Admission by Type of Imprisonment (2013-2016)

\begin{tabular}{|l|l|l|l|l|}
\multicolumn{1}{l}{$\mathbf{2 0 1 3}$} & $\mathbf{2 0 1 4}$ & $\mathbf{2 0 1 5}$ & \multicolumn{1}{l}{2016} \\
\hline $\begin{array}{l}\text { Remanding/Awaiting } \\
\text { Trail }\end{array}$ & $\mathbf{9 3 , 8 4 9}$ & $\mathbf{8 4 , 2 5 9}$ & $\mathbf{7 8 , 7 9 1}$ & \\
\hline Short Term & $\mathbf{4 0 , 2 1 5}$ & $\mathbf{3 1 , 6 5 0}$ & $\mathbf{2 8 , 1 4 1}$ & $\mathbf{3 2 , 1 2 6}$ \\
\hline Long Term & $\mathbf{2 4 , 3 5 2}$ & $\mathbf{2 2 , 8 1 6}$ & $\mathbf{1 6 , 7 6 2}$ & $\mathbf{1 7 , 6 1 6}$ \\
\hline Condemned & $\mathbf{1 0 0}$ & $\mathbf{4 8}$ & $\mathbf{6 4 2}$ & $\mathbf{9 0 4}$ \\
\hline Lifers & - & - & $\mathbf{4 4 9}$ & $\mathbf{1 1 9}$ \\
\hline Detainees & $\mathbf{3 6 1}$ & $\mathbf{6 0}$ & - & $\mathbf{1 , 4 0 9}$ \\
\hline Others & $\mathbf{1 9}$ & $\mathbf{9}$ & - & $\mathbf{1 , 2 7 0}$ \\
\hline Total & $\mathbf{1 5 8 , 8 9 6}$ & $\mathbf{1 3 8 , 8 4 2}$ & $\mathbf{1 2 4 , 7 8 7}$ & $\mathbf{1 4 2 , 8 4 8}$ \\
\hline
\end{tabular}

Source: National Bureau of Statistics

According to the data available on the National Bureau of Statistics (NBS) official website for crime statistics, it shows that 2013 had the highest total prison admission rate of 158,896 followed by 2016 with 142,848 admission figure. The data also shows that 2013 had the highest remanding/awaiting trail inmates, which fell slightly to 84,259 in 2014 and 78,791 in 2015 , but rose again to 89,404 in 2016 . Thus compared to other categories of inmates admitted into the prison system in Nigeria in 2013 to 2016, those on remanding/awaiting trial were the highest.

The data from the NBS also shows that the Nigerian prison had an overcrowding rate of 15,068 in 2015 and 17,886 in 2016. That is, it has a prison capacity of $0.28 \%$ in 2015 and $1.68 \%$ in 2016 , and prison population of $16.01 \%$ in 2015 and $5,62 \%$ in 2016. When the data was broken down by age, it shows that those that fall within 26-50 years were the highest number of those incarcerated, 82,350 in 2015 and 76,220 in 2016.

\section{Community-Based Corrections As Alternative to Incarceration}

Community-based corrections are an approach to punishment. That emphasizes reintegration of the offender into the community through the use of local facilities. It is an alternative to incarceration because It allows the offender to be placed in the community on probation or, in conjunction with imprisonment, in programmes such as parole, furlough, work release, foster homes, or halfway houses (Iwarimie-Jaja, 2007). Community based corrections are used as alternative form of punishment so as to decongest the prison system. Community based corrections is adopted on the philosophy that the criminal needs to be reformed and not punished.

Most community-based correctional services such as probation and other diversion programmes are adopted as intermediate sanction programmes which are strategies aimed at rehabilitating 'situational offenders' or persons who are noncriminal offenders but are forced into unlawful acts due to circumstances beyond their control. Thus instead of sending them to prisons where they are exposed to the subculture of crime and hardened criminals which will debase their sense of respect for the law and order, and make them lose their liberty and their sense of self-esteem, community-based corrections will help 10 make them become law abiding citizens.

Community-based corrections have two key concepts that require clarification. The concepts are 'diversion' and 'reintegration'. Diversion is a process of removing offenders by direct or indirect means from the criminal justice systems and enhancing them into other agencies such as the social welfare. It also means the process of handling juveniles in a system separate from adult criminal offenders and sentencing of 
offenders to community-based correctional facilities rather than to prison. Another important concept in community-based corrections is reintegration. It is a philosophy of punishment that focuses on returning the offender to the community with restored education, employment and family ties. Reid also believes that reintegration is the process of preparing both the community and offender for the latter's return as a productive and accepted citizen. The emphasis is on creating the circumstances around him that will enable him to lead a satisfying and law-abiding life (IwarimieJaja, 2007).

\section{Probation and Suspended Sentence}

Probation is a type of criminal sentencing that permits the offender to remain in the community setting in lieu of serving time in a jail environment. The defendant remains free so long as the terms of the probation are not violated. The conditions of probation might include reporting to the probation officer on a regular schedule, refraining from tin use or abuse of alcohol and/or drugs, maintaining regular employment or continuing schooling, not changing a residence without advanced notice and permission, and not committing i criminal offence while on probation. The particular conditions of probation may vary widely from one defendant to another depending on the offence committed, the offender's criminal history, the presence of victims and how they're heard, and other specific facts and circumstances.

\section{Parole}

According to Wikipedia the World Encyclopedia (2014) parole is the early supervised release of an inmate from a jail sentence. The prisoner is released from jail into the community before the natural conclusion of the original jail term as sentenced. The conditions of parole are similar to those imposed under probation, including regular reporting to a parole officer. The defendant also remains free provided he does not violate the condition of parole.

\section{THEORETICAL FRAMEWORK Marxist- Conflict perspective}

The materialist view of history starts from the premise that the most important determinant of social life is the labour people engaged, especially work that results in the provision of basic necessities of life such as food, clothing and shelter. Marx believes that the way work is socially organized and the impact of technology on the production process have a tremendous impact on every other aspect of society. Marx maintained that everything of value in society results from human labour, that is, it is working men and women that creates the conditions for their own existence (Marx, 1971: 20).
Marx summarized the key elements of this materialist view of history as follows: In the social production of their existence, men inevitably enter into definite relations, which are independent of their will, namely relationship of production appropriate to a given state in the development of their material means of production. Marx divided history into several stages, conforming to broad patterns in the economic structure of society. The most important stages for Marx's argument were feudalism, capitalism, and socialism. For Marx, the central institution of capitalist society is private property, the system by which capital, that is, money, machines, tools, factories, and other materials objects used in production is controlled by a small group of the population. This arrangement leads to two opposing classes, the owners of capital (the bourgeoisie and he workers (proletariat), whose only property is their labour time, which they have to sell to the capitalists. The owners make profits by paying workers less than their desert and, thus, lead to the exploitation of their proletariats and their labour. In Marxist terminology, material forces of production, or means of production, include capital, land, labour, whereas social relations of production refers to the division of labour, and implies class relations.

Economic exploitation leads to oppression, as owners make use of their economic power to gain control of the state, and turn it into a servant of bourgeoisie economic interests. Police power, for instance, is used to enforce property rights and guarantee unfair contracts between the capitalist and the workers. Further, Marx contend that because the dominant or ruling class (bourgeoisie) controls the social relations of production, the dominant ideology in capitalist society is that of the ruling class. Ideology and social institutions, in turn, serve to reproduce and perpetuate the economic class structure. Thus Marx views the exploitative economic arrangements of capitalism as the real foundation upon which the superstructure of social, political, and intellectual consciousness is built.-

According to Marx, the class relations of capitalism embody a contradiction: capitalist need workers, and vice versa, but the economic interest of the two groups are fundamentally opposed to each other. Such contradictions mean inherent conflict and instability, the class struggle. Adding to the instability of the capitalist systems are the inescapable need for ever-wider markets and ever-greater investments in capital to maintain the profits of capitalists. Marx expects that the resulting economic cycles of expansion and contradiction together with tensions that would build as the working class gains greater understanding of its exploited position (by attaining class consciousness) will eventually culminate in a socialist revolution. 
The Marxist-conflict perspective sees prison overcrowding in Nigeria as a consequence of the class struggle between the poor and the dominating class. The ruling class controls and monopolizes the resources and uses them to exploit the poor. Conflict theorists also views crime as a consequence of the class structure of the Nigerian society. It is the structure of society that breeds crime. The structure of the society also divides people into the rich and the poor. The wealthy people, who are mostly politicians, own the most expensive houses in society, while the poor live in squalor. Such situation leaves the poor with no option than to steal from the rich. Majority of those serving time in various correctional institutions in Nigeria including those awaiting trail are people from lower socio-economic background. Many cannot afford the huge amount of money required by experienced private attorneys to prosecute their bails or fight their cases on appeal. They are left in the hands of lawyers from legal aid council, whom many cases, lack the experience and might not be willing to put in the amount of time put in by private attorneys. Many rich people defendants hire Senior Advocates (SAN) to defend their cases. They use their money and influence to secure early release from prison or jails, while the poor do not have such privileges. The poor are also more likely to be arrested for minor crimes than the rich. When arrested, they are also less likely to afford the amount of money required by the police to secure bail. When the cases have been charged to court, they cannot afford huge sums demanded by private attorneys to secure their early release from incarceration. This put them in a precarious situation, as such the poor and people of lower-socio-economic background overpopulate our correctional system. The Nigerian criminal justice system, therefore, favours the rich (bourgeoisie) than the poor (proletariat) because they are arrested more than the rich and also more likely to remain incarcerated for a longtime without being granted bail.

\section{Prisons as Correction Centers}

The penitentiary is set up by law to provide restraint and custody of individuals accused of or convicted for crimes either felony or misdemeanors. The Niger kin prison system dates back to the colonial era and is modeled after the British correction system.

The Nigerian Prison Service derive its operational powers from CAP 366 Laws of the Federation of Nigeria 1990 that charges the prisons; among other things, to take into custody all those certified to be so kept by a court of competent jurisdiction; produce suspects in courts as and when due, identify the causes of antisocial behavior, set in motion mechanisms for their treatment; train inmates for eventual reintegration into society as normal law abiding citizens on discharge; administer prisons farms and industries for this purpose, and in the process generate revenue for the government.

\section{Prison Overcrowding}

Despite all the reforms made by previous Comptroller General of Prisons, the Nigerian penitentiary has failed to reform inmates because of lack of finding and overcrowding. Prison congestion in Nigeria is due largely to the large number of inmates awaiting trial (ATP), otherwise known as remand prisoners. For instance, during the Controller Generals visit to Kaduna prisons after the attempt on jail break found that out of 797 inmates at the prison, 539 were awaiting trail, while 159 were convicted robbers awaiting execution (Oziegbe, 2010).

According to Amnesty International (2008), the Nigerian judicial system is responsible for the problems within the prisons because of the longtime that it takes the courts to grant bail to indigent defendants. Many inmates are kept in detention for a longer time because they cannot meet the bail conditions set by the courts, and also because their bail application has not been heard. In its research, Amnesty International found that lkoyi prison was the most overcrowded prison because 94 percent of all inmates were awaiting trial. Amnesty International also found that 30,000 persons representing over 65 percent of the estimated prisoners population of 46,000 in Nigeria are those awaiting ti id. The problem of congestion has led to many prison facilities to be overstretched and also responsible for many breaks. Similarly, Agomoh et al (2001) identified several factors as being responsible for Nigerian prison congestion. This include high remand/awaiting trial population, congestion and lack of speedy trial; overuse of imprisonment by the courts; abuse of arrest powers and bail conditions by the police; inadequate legal aid facilities, logistics problem relating to transportation of defendants to court; inadequate prison structures; inadequate utilization of non-custodial disposition measure; arid corruption. Orakwe (2008) believes that the increase in the number of ATP or remand prisoners as opposed to those in custody was due to low rate of criminal prosecution in Nigeria. He also points out that congestion is a problem common to urban prisons particularly those of lkoyi, Port-Harcourt, and Owerri. However, Orakwe )O08) believes that the number of persons awaiting trial in custody is becoming relatively stable because the Chief Judges in some States go around periodically freeing those accused of minor offences.

\section{CONCLUSION AND RECOMMENDATION}

The Nigerian criminal justice system, especially the correction facilities are inadequate to accommodate the number of prisoners or detainees sent in from the courts. These prisoners are held in very crowded and appalling conditions. Majority of the inmates are those awaiting trial, many of them have been incarcerated far 
beyond the time they would have spent if convicted. Many that were jailed for misdemeanor offences have become hardened criminals as a result of spending several years associating with repeat violent offenders. Consequently, there is increase in the rate of recidivism. The Chief Justice of most states when on visit to prisons do release inmates detained for minor offenses and those awaiting trials, but this magnanimity has not been able to reduce the problem of prison congestion in Nigeria. The best solution to Nigeria's prison overcrowding problem is to adopt an alternative form of punishment that emphasizes the use of community corrections such as probation and parole. The alternative form of punishment can also take the form of restorative justice, transformative justice, or the abolition of incarceration entirely. The restorative and transformative justice - approaches will require first time offenders receive intervention that would help them not to commit crime again. Such intervention can be in the form of providing the person with useful employment that would help the ex-convict maintain a meaningful life after release from prison or detention. Useful employment after release from prison will also facilitates the process of reintegration for the prison inmate. Another alternative is to provide families of inmates with group counseling. This is significant because it builds a strong -closely connected support group that helps to decrease the chances of the exconvict committing crime again. Lastly, the judges should adopt alternative form of punishment whereby they have the option of sending those with misdemeanor or felonies to transformative programs instead of giving them a sentence. As part of alternative form of punishment, Judges could ask inmates to perform community service such as sweeping the streets or picking up trash from the refuse dumps. If these approaches and recommendations are adhered to strictly, it will help to reduce the problem of Nigerian prison overcrowding.

\section{REFERENCES}

1. Agomoh, U. Adeyemi A. and Oghbor V. (2001) "The Prison Service and Penal Reform in Nigeria: A Synthesis Study, Security and Access to Justice Proramme of the Department for International Development (DFID)", PRAWA

2. Coyle, A.G. (2020) Prison. Britannica. www.britannica.com Accessed 19/10/2020

3. Iwarimie-Jaja, D. (2007) Law and its Administration in Nigeria: A Sociological Approach. $5^{\text {th }}$ Edition. Port-Harcourt: Celwill.

4. Marx, K. and F. Engels (2071) Manifesto of the Communist Party. Moscow: Progress Publishers.

5. National Bureau of Statistics (2017). The Nigerian Prison Service.

6. Olaolu, O., Davidson, I. and Chiemele E. "Nigerian Prisons: Death Traps or Reform Centres?” (2014) This Day, January, 07.
7. Orakwe, I. W. (2008). "The Politics of Prison Congestion." A paper Presented at InterMinisterial Meeting on Human Rights Council at the Federal Ministry of Foreign Affairs, Abuja, $28^{\text {th }}$ February, 2008.

8. Oziegbe, J. (2010). "The Politics of Tackling Prison Congestion in Nigeria. Law and Justice Rights. www.sthash.ql.qkm2bu.dpuf.

9. Rubin, A. \& Deflem, M. (2019). History of the Prison.

10. Rubin, A.T. (2018). The Pre-history of Innovation: A longer view of penal change. Punishment \& Society, 20(2): 192-216

11. Wikipedia, (2014). Alternatives to incarceration". www.wikipediaworld.com 